

doi:

\title{
A phenomenological study of the lived experiences of teenage mothers in coping with complications of preg- nancy in Khaddamari Ward, Jere Local Government Area, Borno State
}

\section{Fenomenológiai indíttatású kutatás tinédzser anyák megélt tapasztalata alapján a szülési komplikációval való megküzdés során, Nigéria Borno Állam Jere Önkormányzat Khaddamari Kórházi Osztály}

Anioke Blessing Nkiruka

University of Debrecen, Faculty of Health, Sóstói út. 2-4 Nyíregyháza, Hungary

M.Sc Health Social Work Student

\section{INFO}

Anioke Blessing Nkiruka
aniokenkiruka@gmail.com

Keywords

phenomenological, lived experience, coping mechanism, teenage pregnancy.
ABSTRACT

Abstract. Objectives: Teenage pregnancy is a world-wide phenomenon and a public health issue so our aim was to identify the contributing factors, and to study perception, complications, effects, challenges and coping mechanisms.

Method: An explorative qualitative research design, snowball sampling, was used. Ten respondents were interviewed using an interview guide in Khaddamari Ward, Jere L.G.A. of Borno State.

Results: The major contributing factor to teenage pregnancy is ignorance and lack of proper sex education both at home and school. Few responses listed traditional roles, cultural expectations, using drugs and alcohol, age discrepancy in relationships, socio-economic factors, sexual coercion and abuse. Most of them perceived fear, guilt and stigmatization and only a few of them said they were excited, proud and accepted. Anemia, preterm labour, cephalo-pelvic disproportion, obstructed labour and vesico-vaginal fistula were common complications. Almost all of them dropped out of school. 
Conclusion: Based on these findings of the study, a collaborative effort by all stakeholders involved should be employed in combating the complications of teenage pregnancy.

\section{Kulcsszavak}

jelenség, megélt élmény, megküzdési mechanizmus, tinédzser terhesség.
Absztrakt. Cél: Tinédzser terhesség előfordul szerte a világban, s mivel népegészségügyi téma, kutatásunk célja feltárni a helyzetet előidéző a tényezőket, komplikációkat, hatásokat, kihívásokat, megküzdési mechanizmust, és hogy mit érzékel a tinédzser.

Módszer: Feltáró kvalitatív kutatást alkalmaztunk, a hólabda módszert. 10 válaszadóval készítettünk interjút, amiben segítségünkre volt egy kérdező a nigériai Borno állambeli Jere önkormányzat Khaddamari kórházi osztályán.

Eredmények: Legfőbb tényező a tudatlanság és a megfelelő szexuális felvilágosítás hiánya, otthon és az iskolában egyaránt. Néhány válaszadó megemlítette a hagyományos szerepeket, kulturális elvárást, drog és alkohol használatot, korkülönbséget, szocio-gazdasági tényezőket, kényszerítést és erőszakot. Többségük félelmet, büntudatot és megbélyegzést érzékelt, csak néhányan mondták azt, hogy izgatottak, büszkék voltak, és elfogadták őket. Leggyakoribb komplikációk: anémia, koraszülés, a medence és fej közötti aránytalanság, elakadás a szülőcsatornában és sipoly. Szinte mindegyik kimaradt az iskolából.

Következtetés: A kutatás eredményei alapján elmondható, hogy az összes résztvevő együttes erőfeszítésével a tinédzserkori terhesség szövődményei megakadályozhatók lennének.

\section{Introduction}

Teenage pregnancy is a serious cankerworm that has eaten itself deep into the fabric of our societies in this contemporary period (Alabi and Oluwafemi, 2017). Teenage pregnancy (synonymous with adolescent pregnancy) is a complex issue with many reasons for concern and a natural human occurrence that is ill-fitting in our modern society (Cherry et al., 2015). It is a term which usually refers to women who have not reached the legal adulthood to become pregnant. It is a case of under-aged pregnantgirls usually between ages 13 and 19 .

\section{Global statistics on teenage pregnancy}

Almost 16 million between ages 15 and 19, and 2.5 million girls under 16 give birth each year in developing regions (United Nations Population Fund, 2015). Globally, the complications during pregnancy and childbirth are the leading cause of death for 15-19 year-old girls (World Health Organization, 2015). Every year, up-to 3.9 million girls between ages 15 and 19 undergo unsafe abortions (Darroch et al., 2016). From the estimated 5.6 million abortions, which occur each year among adolescent girls 
between ages 15 and 19,3.9 million are unsafe and contribute to maternal mortality, morbidity and lasting health problems (Darroch et al., 2016).

Adolescent mothers (between ages 10 and 19) face higher risks of eclampsia, puerperal endometritis and systemic infections than 20-24 year-old women, and babies of adolescent mothers face higher risks of low birth weight, preterm delivery and severe neonatal conditions (World Health Organization, 2015).

\section{Nigerian statistics on teenage pregnancy}

According to the Nigerian Demographic and Health Survey (2013) about 23\% of women between ages 15 and 19 began childbearing, of which $17 \%$ already had their first child and $5 \%$ was pregnant with the first child. Also, $32 \%$ of teenagers were living in rural areas, while $10 \%$ of them in the urban areas of Nigeria. Disparities within the different geopolitical zones in Nigeria:

Northwest (36 percent)

Northeast (32 percent)

North Central (19 percent)

South Central (12 percent)

South East (8 percent) and

South West (8 percent).

\section{Research objectives}

1. To identify the contributing factors to teenage pregnancy.

2. To determine the perceptions of teenage mothers towards teenage pregnancy.

3. To determine the complications of teenage pregnancy to the mother and child.

4. To determine the effect or outcome of teenage pregnancy.

5. To determine the challenges and coping mechanism of the teenage mothers.

\section{Research questions}

1. What are the contributing factors to teenage pregnancy?

2. What are the perceptions of teenage mothers towards teenage pregnancy?

3 . What are the complications of teenage pregnancy to the mother and child?

4. What are the outcomes of teenage pregnancy?

5 . What are the challenges and coping mechanisms of teenage mothers? 


\section{Theoretical / conceptual model / framework}

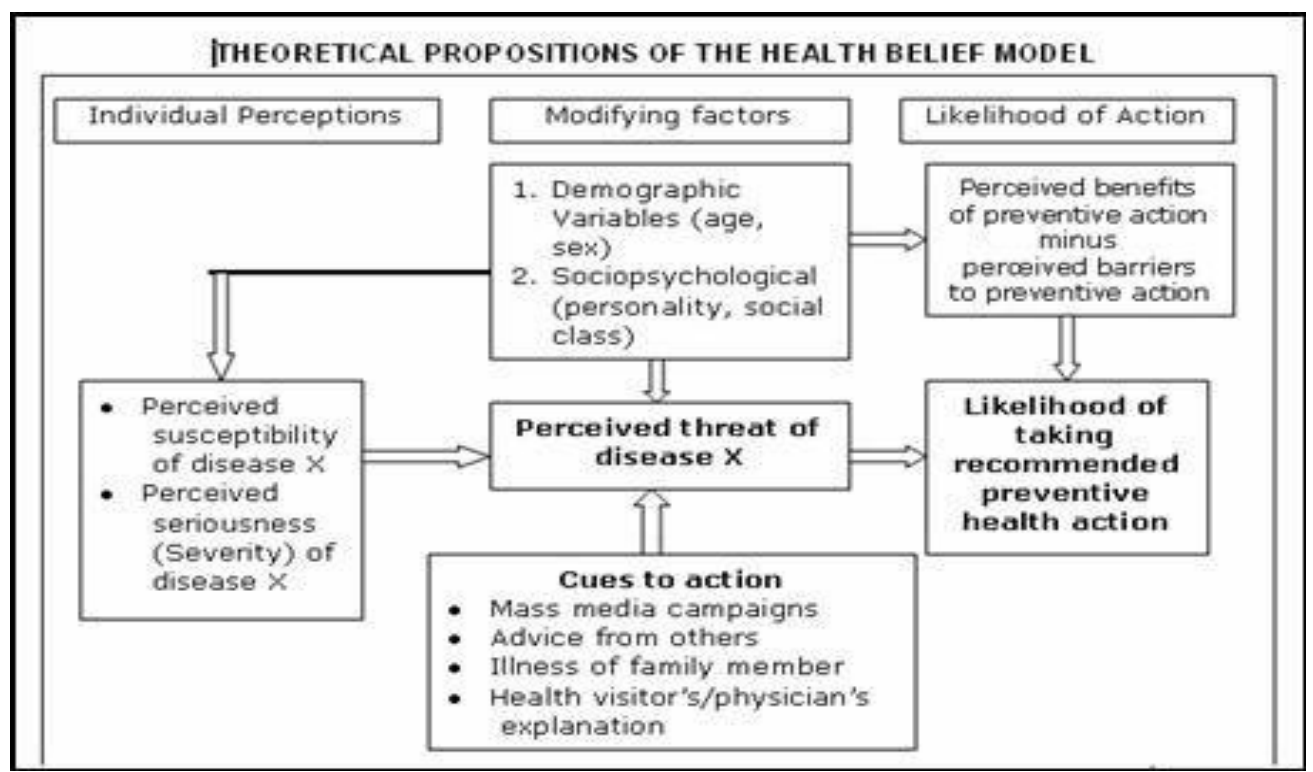

Source: (http 1).

Figure 1: The Health Belief Model

\section{Theoretical constructs}

There are six major concepts in Health Belief Model:

1. Perceived susceptibility: engaging in behaviours that decreases the risk of health problem development when a person perceives that he/she has a particular health problem.

2. Perceived severity: assessing the severity of a health problem and its future consequences subjectively.

3. Perceived benefits of taking preventive actions: assessing the effectiveness of decreasing risk of the disease by participating in a health-promoting.

4. Perceived barriers to taking that action: hindrances to changes in behaviour of the individual.

5. Enabling or modifying factors: health-related behaviours are affected by modifying variables by affecting perceived seriousness, susceptibility, benefits and barriers indirectly.

6. Cues to action: This could be internal or external. Internal cues to action are physiological such as pain and symptoms. External cues to action are events or information friends or family members, the media, or health care providers (Skinner et.al., 2015). 


\section{Research methodology}

An explorative qualitative research design was used. In-depth interviews and openended questions were the instruments for data collection, which were applied with the help of a guide. Snowball sampling method was used to select respondents for the research. The sampling size consisted of 10 respondents. A thematic analysis was done, and before that respondents were asked for their consent to audio-tape the interview which was transcribed verbatim and analysed using Descriptive Statistics (Categorization tables, and Figures).

\section{Results and findings}

\begin{tabular}{|c|c|c|c|c|c|c|c|c|c|}
\hline $\begin{array}{l}\text { Teenage } \\
\text { mothers }\end{array}$ & $\begin{array}{c}\text { Age } \\
\text { (years) }\end{array}$ & Religion & $\begin{array}{c}\text { Highest educational } \\
\text { qualification }\end{array}$ & $\begin{array}{c}\text { Economic } \\
\text { status of } \\
\text { family }\end{array}$ & $\begin{array}{l}\text { Occupation } \\
\text { of parents }\end{array}$ & $\begin{array}{c}\text { Number } \\
\text { of } \\
\text { children }\end{array}$ & $\begin{array}{c}\text { Sex } \\
\text { education }\end{array}$ & $\begin{array}{c}\text { Intake } \\
\text { of } \\
\text { alcohol }\end{array}$ & $\begin{array}{c}\text { Who } \\
\text { they } \\
\text { were } \\
\text { staying } \\
\text { with }\end{array}$ \\
\hline $\begin{array}{l}\text { Respondent } \\
\text { one }\end{array}$ & Eighteen & Christianity & Secondary school (SS 2) & Poor & Farmers & One & Taught & No & Uncle \\
\hline $\begin{array}{l}\text { Respondent } \\
\text { two }\end{array}$ & Fifteen & Islam & $\begin{array}{l}\text { Secondary school } \\
\text { (JSS3) }\end{array}$ & Poor & Farmers & None & Taught & No & Husband \\
\hline $\begin{array}{l}\text { Respondent } \\
\text { three }\end{array}$ & Eighteen & Christianity & Secondary school (SS2) & Poor & Business & One & Not Taught & No & Parents \\
\hline $\begin{array}{l}\text { Respondent } \\
\text { four }\end{array}$ & Nineteen & Christianity & Secondary school (SS3) & Poor & $\begin{array}{l}\text { Contractor } \\
\text { and } \\
\text { business }\end{array}$ & One & Not Taught & Yes & $\begin{array}{l}\text { Single } \\
\text { parent } \\
(\mathrm{Dad})\end{array}$ \\
\hline $\begin{array}{l}\text { Respondent } \\
\text { five }\end{array}$ & Fifteen & Christianity & $\begin{array}{l}\text { Secondary school } \\
\text { (JSS3) }\end{array}$ & Poor & Traders & One & Taught & Yes & Parents \\
\hline $\begin{array}{l}\text { Respondent } \\
\text { six }\end{array}$ & Seventeen & Christianity & Secondary school (SS1) & Poor & Farmers & One & Not Taught & No & Aunt \\
\hline $\begin{array}{l}\text { Respondent } \\
\text { seven }\end{array}$ & Sixteen & Christianity & Secondary school(SS2) & Poor & Business & One & Taught & No & Parent \\
\hline $\begin{array}{l}\text { Respondent } \\
\text { eight }\end{array}$ & Eighteen & Christianity & Secondary school (SS2) & Poor & Traders & None & Taught & No & Parent \\
\hline $\begin{array}{l}\text { Respondent } \\
\text { nine }\end{array}$ & Sixteen & Christianity & $\begin{array}{l}\text { Secondary school } \\
\text { (JSS3) }\end{array}$ & Poor & Farmers & One & Taught & No & Aunt \\
\hline $\begin{array}{l}\text { Respondent } \\
\text { ten }\end{array}$ & Sixteen & Islam & $\begin{array}{l}\text { Secondary school } \\
\text { (JSS3) }\end{array}$ & Poor & Farmers & One & Not Taught & No & Husband \\
\hline
\end{tabular}

Source: (FIELD SURVEY, 2016).

Table 1. Socio-Demographic Information of the Respondents

\section{Contributing Factors}

\begin{tabular}{|l|l|}
\hline Majority & Least \\
\hline $\begin{array}{l}\text { Lack of proper sex education/ inadequ- } \\
\text { ate knowledge about safe sex, influence } \\
\text { of friends and lack of parental guidance. }\end{array}$ & $\begin{array}{l}\text { Traditional roles/ cultural expectations, intake of } \\
\text { drugs and alcohol use, age discrepancy in relati- } \\
\text { onships, socio-economic factors, sexual co- } \\
\text { ercion and abuse }\end{array}$ \\
\hline
\end{tabular}

Source: (FIELD SURVEY, 2016).

Table 2: Categorization Table on the Contributing factors to Teenage Pregnancy Among Teenage Mothers. 




Source: (FIELD SURVEY, 2016).

Figure 2: Perceptions of Teenage Mothers towards Teenage Pregnancy

\begin{abstract}
Majority
Anemia preterm/premature labour, cephalopelvic disproportion leading to obstructed labour and subsequent ceasarean section and vesico vaginal fistula (VVF). The baby-faced complications like IUFD, Jaundice and Fetal growth retardation and fetal distress
\end{abstract}

Source: (FIELD SURVEY, 2016).

Figure 3: Complications of Teenage Pregnancy to the Mother and Child

\begin{tabular}{|l|l|}
\hline \multicolumn{2}{|c|}{ Effect (Outcomes) } \\
\hline Almost all Respondents & Just one Person \\
\hline $\begin{array}{l}\text { Dropped out of school and be- } \\
\text { came sick intermittently. }\end{array}$ & $\begin{array}{l}\text { Perceived as unclean, shunned abandoned and rejected } \\
\text { by family members, friends and boyfriend/husband }\end{array}$ \\
\hline
\end{tabular}

Source: (FIELD SURVEY, 2016).

Table 3: Categorization Table on the Effect (Outcomes) of Teenage Pregnancy.

\begin{tabular}{|l|l|l|}
\hline \multicolumn{3}{|c|}{ CHALLENGES } \\
\hline Prevalent & Below Average & Least \\
\hline $\begin{array}{l}\text { Inability or difficulty in providing } \\
\text { adequate financial resources to sup- } \\
\text { port the child }\end{array}$ & $\begin{array}{l}\text { Rejection by family mem- } \\
\text { bers, friends and boyfri- } \\
\text { end/husband }\end{array}$ & $\begin{array}{l}\text { Feelings of self- } \\
\text { destruction (Su- } \\
\text { icidal attempt) }\end{array}$ \\
\hline \multicolumn{2}{|c|}{ COPING MECHANISMS } \\
\hline Prevalent & Below Average & Least \\
\hline $\begin{array}{l}\text { Support from parents or relatives to } \\
\text { enable her go back to school and gain } \\
\text { a brighter future for myself and my } \\
\text { child }\end{array}$ & $\begin{array}{l}\text { Thinking positive and } \\
\text { working hard to get a good } \\
\text { job to care for myself and my } \\
\text { child }\end{array}$ & $\begin{array}{l}\text { Giving a deaf ear } \\
\text { to what people } \\
\text { said about me }\end{array}$ \\
\hline
\end{tabular}

Source: (FIELD SURVEY, 2016).

Table 4: Categorization Table on the Challenges and Coping Mechanisms of Teenage Mothers with Complicated Pregnancy. 


\section{Discussion of major findings}

\section{Socio-demographic information of the respondents}

It was apparent that the majority of the respondents were sixteen and eighteen yearold girls, few were 15 and some were between ages seventeen and nineteen years. This is in accordance with the research of the World Health Organization (2013) which revealed that teenage pregnancy has hit hard developed and developing communities, 16 million girls aged 15 to 19 give birth every year, with the majority of these pregnancies occurring in developing countries.

Regarding their educational qualification, the result revealed that all of them went to secondary school and were about to complete their secondary school education. Our findings were similar to a recent study conducted by Angeline et al. (2014) which states that teenage mothers have less possibility to finish their studies after engaging in early pregnancy, therefore the major impact (outcome) of teenage pregnancies is the high incidence of school dropouts.

\section{Research Question I}

What are the contributing factors of teenage pregnancy among unmarried girls in Khaddamari ward, Jere L.G.A. of Borno State?

From the findings presented above, it is clear that the contributing factors to teenage pregnancy in Khaddamari ward, Jere L.G.A. of Borno State are the following: the majority of the respondents said that the contributing factor to teenage pregnancy is lack of proper sex education or inadequate knowledge about safe sex, the influence of friends and lack of parental guidance, while other respondents mentioned traditional roles / cultural expectations, intake of drugs and alcohol use, age discrepancy in relationships, socio-economic factors, sexual coercion and abuse. This disagreed with the study conducted on the causes (contributing factors) to teenage pregnancy by James and Abieyuwa (2013) in the Department of Obstetrics and Gynaecology, University of Benin. Peer pressure to have sex $(71.8 \%)$ had the highest rating in the respondents' perceptions pertaining to the causes of teenage pregnancy, other items were ignorance on the basics of sexuality and pregnancy $(60.1 \%)$, and being forced or coerced/refusal by boys/men to use condoms (52.1\%). These findings agree with the study conducted by Adeyanju and Afolayan (2012) on the health and social problems of teenage pregnancy and future childbearing in the Department of Community Health Nursing, Faculty of Health Sciences, Niger Delta University, Amassoma community, Wilberforce Island, Bayelsa State, Nigeria. The result indicated that the causes (contributing factors) of teenage pregnancy include ignorance, sexual harassments, low education, marital instability, early marriage, sexual abuse, modernization, religion, culture and misconception about contraceptives use.

This also agreed with the recent study conducted by Angelina et al. (2014) to determine the lived experiences of early pregnancy among high and low performing students in terms of the causes (contributing factors). Results show that curiosity, lack of sexual knowledge, financial and family problems and uncontrolled emotions result in pregnancy among teenagers. 
This also agreed with the study conducted by Sonfield et al. (2013) on the contributing factors to teenage pregnancy which revealed that teenage girls undergo a lot of pressure to have sex, to look sexy and to conform to the stereotypes that the opposite sex sees as attractive.

\section{Research questions II}

What are the perceptions of teenage mothers towards teenage pregnancy?

In Figure 2, the prevalent perception was that they were afraid, guilty and stigmatized while others said they were ashamed and rejected by family members, friends and boyfriend/husband and a few of them said they were excited, proud and accepted by family members, friends and boyfriend/husband. This response also corroborated the recent study conducted by Angeline et al. (2014) which found that teenage mothers face a lot of challenges after pregnancy like providing proper care and meeting the needs of their child. The sociologist Rowlingson (2011) states that some teenagers seemingly do not grasp the connection between sex and pregnancy thus "often reported that they are being shocked and surprised to find out that they are pregnant". The society often has the common belief that a pregnant girl while still living with the parents is a disappointment, thus, the teenager will find it difficult to reveal her pregnancy to their parents, and she is overwhelmed by guilt and fear.

Our findings corroborate the study on the perceptions of teenage pregnancy conducted by the World Health organization (2013) which reveals that teenage pregnancy in developed countries is usually outside marriage and carries a social stigma in many communities and cultures. Our findings also agree with the study conducted on the perception of teenage mothers towards teenage pregnancy by James and Abieyuwa (2013) in the Department of Obstetrics and Gynecology University of Benin. The results show that the majority of the respondents held a negative perception about teenage pregnancy with over $85 \%$ regarding it as wrong and considered it to be associated with medical, socio-economic and educational problems.

\section{Research Question III}

What are the complications of teenage pregnancy on the mother and child?

From Figure 3 it can be seen that the majority of the respondents said that the complications they faced were anemia, preterm/premature labor, cephalo-pelvic disproportion (CPD) leading to obstructed labour and subsequent Cesarean section and vesico-vaginal fistula (VVF), while few of the respondents said their complications were high blood pressure, sexually transmitted infections (STIs) such as HIV/AIDS and puerperal psychosis.

This finding is similar to the research conducted by the World Health Organization (2013) which reveals that teenage mothers are at risks of low birth weight, premature labour, anemia and pre-eclampsia which are connected to the biological age of 15-19, as it was observed in teen births even after controlling other risk factors (such as utilization of antenatal care etc.).

Our findings also agree with the study conducted by Adeyanju and Afoloyan (2012) on the health and social problems of teenage pregnancy and future childbearing in the Department of Community Health Nursing, Faculty of Health Sciences, Niger Delta University, Amassoma community, Wilberforce Island, Bayelsa State, Nigeria. 
Their result indicates that the reported complications (medical problems) of teenage pregnancy includes difficulty in childbirth, anemia, depression, threatened abortion, premature delivery, vesico vaginal fistula, high blood pressure, maternal and child mortality and haemorrhage.

Our findings also agree with the study conducted by Babafemi and Adelek (2012) which states that the social stigma that once was put on out-of-wedlock pregnancy, especially on teenagers, has declined. However, the risks of serious health consequences may remain for the teenage mother and her child. In some cultures, teenage pregnancy is regarded as normal, a God-given gift and proof of fertility of the female teenager.

\section{Research Question IV}

\section{What are the outcomes of teenage pregnancy?}

Table 3 shows that almost all the respondents dropped out of school and became sick intermittently, whereas just one person was perceived as unclean, abandoned and rejected by family members, friends and boyfriend/husband.

Our finding is in agreement with the research conducted by the World Health Organization (2013) which reveals that teenage pregnancy has hit hard developed and developing communities, generating a set of problems such as frequent absenteeism and form repetition in schools, dropping out of schools and poor academic performance.

This is also consistent with the study conducted by Angeline et al. (2014) which has attempted to determine the lived experiences of early pregnancy among high and low performing students in terms of the outcome. Results have shown that the major outcome of teenage pregnancies is the high incidence of school dropouts, low job qualification, early marriage and stereotypes of the society.

This is also in consonance with a study conducted by Adeyanu and Afolayan (2012) on the health and social problems of teenage pregnancy and future childbearing in the Department of Community Health Nursing, Faculty of Health Sciences, Niger Delta University, Amassoma community, Wilberforce Island, Bayelsa State, Nigeria. The result indicates that the health outcomes and social problems of teenage pregnancy include neglect, low level of education, unstable marriage, unstable marriage, poverty, financial dependency and lack of job skills.

\section{Research Question V}

\section{What are the challenges and coping mechanisms of teenage mothers?}

Table 4 shows that the biggest challenge that teenage mothers need to face is the inability or difficulty in providing adequate financial resources to support the child. Some of them said they were rejected by family members, friends and boyfriend/husband while few of them reported on feelings like self-destruction (suicidal attempt). The prevalent coping mechanism is triggered by the support from parents or relatives to enable her to go back to school and gain a brighter future for herself and the child. Some of them said that they are thinking in a positive way and working hard to get a good job to care for themselves and their child, while few of them said that she was giving a deaf ear to what people said about her.

This is in consonance with a recent study conducted by Angeline et al. (2014) on the early pregnancy lived experiences among high and low performing students in 
terms of the challenges faced by teenage mothers. Results show that teenage mothers face a lot of challenges after pregnancy like difficulties in providing proper care and financial assistance to support or meet the needs of their child, difficulties in bringing back self-confidence, feeling of insecurity among schoolmates who already finished their studies, and difficulties in giving time to her child because she is giving much time to work.

This is also in consonance with a recent study conducted by Angeline et al. (2014) on the lived experiences in early pregnancy of high and low performing students in terms of the coping mechanisms. Results show that for the majority of them the coping mechanism is taking care of the child, thinking in a positive way and doing their best to rear or give a brighter future to the child. Coping mechanism also involved saving money and looking forward to pursuing their studies.

This is also in agreement with the study conducted by Sonfield et al. (2013) on the challenges of teenage pregnancy, which reveals that teenage pregnancy is considered unusual in the society. This can also be seen as an early warning sign of inequality in a society, and these teenage mothers face a challenge to get adequate financial support.

\section{Interventions/recommendations}

1. Policy Engagement: Policies on compulsory and undiluted sex education in schools should be enforced in school so that teenagers will have the knowledge to differentiate between right and wrong. Policies on providoing contraceptives should be enforced. 2. With the help of community engagement they should be educated on preventive measures of teenage pregnancy.

3. Provision of effective and efficient health services by the government.

4. Comprehensive sex education eg. on how to cooperate with the sex partner.

5. Parents and Family Support as family is an important institution where a child lives. Parents should learn to say no to giving out their children for marriage at teen ages, and they also should be coached on preventive measures against pregnancy or otherwise abstain from it.

6. Asset building to empower adolescent girls to become self-sufficient and reliant; such as teaching them some skills and handcraft that they can do in their leisure time which will be of economic value.

7. Youth friendly centres should be established by the government that will embark on a massive campaign to prevent early pregnancy and encourage teenage mothers to go back to school.

\section{Conclusion}

Based on the analysis and findings of our study, we can say that there is an alarming increase in teenage pregnancy, therefore a collaborative effort of parents, guardians, health professionals, teachers/educators and clergymen should be put into this issue. Moreover several actors should take part in educating the youths, especially teenagers, 
on sexual behaviour. Several sociodemographic factors have been associated with teenage pregnancy which can lead to serious complications. Therefore, interventions that target these factors are important in reducing teenage pregnancy.

\section{References}

1. ADEYANJU A. B. and AFOLAYAN J. A. (2012). Health and social Problems of Teenage Pregnancy and Future Childbearing. Research Journal of Medical Sciences 6 (5): 251-260, 2012. ISSN: 1815-9346. With Medwell Journals, 2012.

2. ALABI O. T. and OLUWAFEMI O. I. (2017). Teenage Pregnancy in Nigeria: Causes, Effect and Control. International Journal of Academic Research in Business and Social Sciences, Vol. 7, No. 2 17-32 ISSN: 2222-6990

3. ANGELINE M. P., VERZOSA D. R., COMING D. N. S. and RONALISA G. A. (2014). Lived experiences of early pregnancy among teenagers among high and low performing mothers: a phenomenological study. European scientific journal January, 2014 edition vol.10, No. 2 ISSN: 1857-7881 (print) e-ISSN 1857-7431.

4. BABAFEMI A. A. and ADELEKE A. J. (2012). Health and Social Problems of Teenage Pregnancy and Future Childbearing in Amassoma Community, Bayelsa State, Nigeria. Research Journal of Medical Sciences 6(5):251- 260. DOI: https://doi.org/10.3923/rjmsci.2012.251.260

5. CHERRY, ANDREW L. and MARY D. E. (2015). International Handbook of Adolescent Pregnancy: "Biological Determinants and Influences Affecting Adolescent Pregnancy”. Medical, Psychosocial and Public Health Responses. By Andrew Cherry and Mary E. Dillon, 39-53. New York: Springer Science \& Business Media, 2014. DOI: https://doi.org/10.1007/978-1-4899-8026-7 2

6. DARROCH J. E., WOOG V., BANKOLE A. and ASHFORD L. S. (2016). Adding it Up: Costs and Benefits of Meeting the Contraceptive Needs of Adolescents. New York, NY: Guttmacher Institute; 2016.

7. https://hu.pinterest.com/pin/442337994624332166/ (Webpage of Pinterest); Visited: 04. 2020.

8. JAMES A. O. and ABIEYUWA P. O. (2013). Adolescents' perspective regarding adolescent pregnancy, sexuality and contraception. Asian Pacific Journal of Reproduction. March 2013, Vol. 2(1):58-62, DOI: https://doi.org/10.1016/s2305$\underline{0500(13) 60118-9}$

9. NIGERIAN DEMOGRAPHIC AND HEALTH SURVEY. (2013). Retrieved from: https://www.unicef.org/nigeria/sites/unicef.org.nigeria/files/2018-09/Nigeria-demographic-and-health-survey-2013.pdf

10. ROWLINGSON M. (2011). Teenagers are being shocked and surprised to find out that they are pregnant as they are regarded by the society as a disappointment. 2011 publications

11. SKINNER C. S., TIRO and CHAMPION V. L. (2015). The Health Belief Model. In Glanz K., Rimer B. K. and K. Viswanath K. (Eds.), Health Behavior, Theory, Research and Practice. 2015. 75-94. 
12. SONFIELD A., HASSTEDT K., JAVANAUGH L. and ANDERSON R. (2013). The Social and Economic Benefits of Women's Ability to Determine Whether and When to Have Children. New York, Guttmacher Institute. Retrieved from: www.guttmacher.org/pubs/social-economic-benefits.pdf

13. UNFPA. (2015). Girlhood, not motherhood: Preventing adolescent pregnancy. United Nations Population Fund UNFPA, New York. ISBN: 978-0-89714-986-0.

14. WORLD HEALTH ORGANIZATION. (2013). The Prevention and Management of Unsafe Abortion. Report of a Technical Working group. Retrieved from: http://whqlibdoc. who.int/hq /1992 /WHO MSM 92.5.pdf

15. WORLD HEALTH ORGANIZATION. (2018). Adolescent Pregnancy. Retrieved from: https:/www.who.int/en/news-room/fact-sheets/detail/adolescent-pregnancy 